\title{
Resistance to Antibiotics in Strains of Staphylococcus spp., Enterococcus spp. and Escherichia coli Isolated from Rectal Swabs of Pigs
}

\author{
M. KOLÁ $\check{R}^{1}$, J. BARDOŇ ${ }^{1,2}$, I. VÁGNEROVÁ ${ }^{1}$, P. SAUER ${ }^{1}$, D. KOUKALOVÁ ${ }^{1}$, J. PETRŽELOVÁ $^{1}$, \\ L. ČEKANOVÁ ${ }^{1}$, R. POSPÍŚIL ${ }^{3}$
}

${ }^{1}$ Department of Microbiology, Faculty of Medicine and Dentistry, Palacký University Olomouc, Czech Republic ${ }^{2}$ State Veterinary Institute Olomouc, Czech Republic

${ }^{3}$ Department of Financial Law and Economics, Faculty of Law, Palacký University Olomouc, Czech Republic

Received April 30, 2007

Accepted November 15, 2007

\begin{abstract}
Kolář M., J. Bardoň, I. Vágnerová, P. Sauer, D. Koukalová, J. Petrželová, L. Čekanová, R. Pospíšil: Resistance to Antibiotics in Strains of Staphylococcus spp., Enterococcus spp. and Escherichia coli Isolated from Rectal Swabs of Pigs. Acta Vet Brno 2008, 77: 103-1100.

The study aimed at determining the level of resistance of selected bacterial species (Staphylococcus spp., Enterococcus spp., Escherichia coli) isolated from rectal swabs of pigs to antimicrobial agents.

The tested strains were isolated from piglets aged 7 to 30 days. Bacterial species were identified by standard microbiological techniques and susceptibility to antibiotics was determined quantitatively by the standard microdilution method. Resistance of the Staphylococcus aureus strain to oxacillin was confirmed by detection of the mecA gene and PBP2a. A total of 115 Staphylococcus spp. isolates were collected. In the case of Staphylococcus aureus, the methicillinresistant strain (MRSA) was identified. Moreover, higher frequency of coagulase-negative staphylococci with minimum inhibitory concentration of oxacillin $\geq 0.5 \mathrm{mg} / \mathrm{l}$ was noticed. Inducible resistance to clindamycin in the Staphylococcus hominis strain was also detected. The strains of Enterococcus spp. (61 isolates) exhibited high resistance to tetracycline (98.5\%), erythromycin (86.8\%) and chloramphenicol (54.4\%). Vancomycin-resistant enterococci were not isolated. In the case of Escherichia coli strains (111 isolates), higher frequency of resistant strains to tetracycline $(81.1 \%)$ and ampicillin $(62.2 \%)$ was documented. Resistance to fluoroquinolones and production of broad-spectrum $\beta$-lactamases was not noticed.

The presented study may be considered as a pilot project assessing the prevalence of resistant bacteria in piglets kept on a single farm. It demonstrated the presence of resistant strains of Staphylococcus spp., including one MRSA strain, Enterococcus spp. and Escherichia coli. These strains may be present as a result of postnatal colonization with both bacterial microflora of dams and environmental microflora.
\end{abstract}

Pigs, rectal swabs, bacterial resistance, MRSA, Czech Republic

Bacterial resistance to antimicrobial agents has become a serious problem both in human and veterinary medicine. It is related to an excessive use of antibiotics which represent an important part of therapy and, in selected cases, prevention of bacterial infections. On the other hand, they contribute to the development and spread of bacterial resistance to their effects. It must be pointed out that bacterial resistance is not a theoretical issue without a practical impact. In human medicine, multiresistant bacterial strains are associated with higher rates of death from the infections they cause. Similar data are available in animal medicine. A case of lethal infection in a dog caused by a methicillin-resistant Staphylococcus aureus strain - MRSA has been described (Waller 2005).

Bacteria with prominent clinical importance and bacterial resistance include staphylococci (especially methicillin-resistant strains of Staphylococcus aureus and coagulase-negative staphylococci), enterococci (in particular vancomycin-resistant isolates) and enterobacteria producing broad-spectrum ß-lactamases (e.g. ESBL and AmpC enzymes). At present, 
human medicine is characterized by a worldwide increase in the prevalence of MRSA. MRSA have also been confirmed in veterinary practice, e.g. in cattle, chickens, cats, dogs, horses and a seal (Gortel et al. 1999; Lee 2003; Lilenbaum et al. 1998; O'Mahony et al. 2005). There is concern about increasing data on the interspecific transfer of MRSA, i.e. between animals and humans. Seguin et al. (1999) documented prevalence of identical MRSA in horses and their breeders and a similar relation was suggested by Weese et al. (2005). Also Van Duijkeren (2004) assumed a MRSA transfer between humans and dogs. MRSA strains were isolated from animals and veterinary office staff, as described by O'Mahony et al. (2005). Although the impact of methicillin-resistant coagulase-negative staphylococci in veterinary medicine has not been specified, these strains may represent a reservoir of resistance genes (Vengust et al. 2006; Busscher et al. 2006). The same is true for vancomycin-resistant enterococci (VRE) as their prevalence both in animals and humans has already been proved in the Czech Republic (Kolár et al. 2000, 2005). Broad-spectrum ß-lactamases in enterobacteria of animal origin have not been noticed in the Czech Republic as yet. However, this is one of the most serious issues concerning antibiotic resistance in humans, with an impact on higher mortality of patients.

It is not unrealistic to presume that multiresistant bacterial strains may enter the human food chain as part of foods of animal origin; they may also colonise or infect people who are in contact with animals. It is well known that pork makes up a significant part of the average Czech consumer basket. Therefore, the study aimed at determining the susceptibility of Staphylococcus spp., Enterococcus spp. and Escherichia coli strains isolated from rectal swabs of piglets to antimicrobial agents. Thus, with respect to the monitoring of antibiotic resistance, the study is a pilot project.

\section{Materials and Methods}

The tested strains of Staphylococcus spp., Enterococcus spp. and Escherichia coli were isolated from 100 piglets kept on a single farm (a farrowing house) in the Olomouc Region. The piglets, aged 7 to 30 days, were clinically healthy and had not been administered any antibiotics during their lives. All samples were obtained within the same day. According to the breeder's data, no antibiotics were administered to the sows in the week prior to farrowing. At the time of sampling, the total number of piglets of the given age category kept at the farm was 113. The strains were isolated from 100 rectal swabs collected with a kit containing a swab and a transport medium (Venturi Transystem - Amies agar gel transport medium with charcoal). The piglets were randomly selected for sampling from the aforementioned group of 113 individuals. After being delivered to the laboratory, the swabs were inoculated onto a solid medium (blood agar, Endo agar, XLD agar, Becton Dickinson) subsequently incubated aerobically at $37^{\circ} \mathrm{C}$ for $24 \mathrm{~h}$. Following isolation of enterococci, the swabs were brokenoff into meat-peptone broth with $6.5 \% \mathrm{NaCl}$, once again incubated at $37{ }^{\circ} \mathrm{C}$ for $24 \mathrm{~h}$. Then the liquid medium was transferred with a calibrated loop on a blood agar. Twenty four-hour cultivation followed at $37^{\circ} \mathrm{C}$ and under aerobic conditions.

Identification of the aforementioned bacterial strains was carried out by standard microbiological techniques using commercially produced sets ENTEROtest16, EN-COCCUStest and STAPHYtest16 (Pliva-Lachema Diagnostika). In the case of Staphylococcus aureus strains, another commercial set was utilized, Staphaurex Plus $^{\circledR}$ (Remel) capable of detecting the clumping factor, protein A and other specific antigens characteristic for Staphylococcus aureus. For identification of enterococci, the PYRAtest for pyrrolinyl arylamidase (Pliva-Lachema Diagnostika) was used as well. When various species of Staphylococcus spp. and Enterococcus spp. were detected in a single sample, all strains of the different species were included in the database. When both haemolytic and non-haemolytic strains of Escherichia coli were present simultaneously, both isolates were included.

To assess susceptibility of the isolated bacteria, the standard microdilution method determining minimum inhibitory concentrations (MIC) of the tested antibiotics (CLSI 2007; CLSI 2006) was used. At the end of the epizootic-epidemiological chain there are humans in whom multiresistant bacteria of animal origin may, under certain circumstances, cause severe diseases. Therefore, the susceptibility tests utilised breakpoints (susceptibility/ resistance criteria) defined by the National Reference Laboratory for Antibiotics, National Institute of Public Health, Prague and commonly used in the Czech Republic for evaluating resistance in human medicine.

The $\mathrm{MIC}_{50}$ and $\mathrm{MIC}_{90}$ values were calculated as $50 \%$ and $90 \%$, respectively, percentiles of the MIC values of individual antibiotics. The reference strains Escherichia coli ATCC 25922, Escherichia coli ATCC 35218, Pseudomonas aeruginosa ATCC 27853, Staphylococcus aureus ATCC 29213, Staphylococcus aureus ATCC 25923 and Enterococcus faecalis ATCC 29212 served for protocol quality control.

Detection of the penicillin-binding protein 2a (PBP2a) in Staphylococcus aureus was performed by latex 
agglutination (MRSA-Screen test, Denka Seiken Co.), an adequate alternative to PCR detection of the $m e c A$ gene (Cavassini et al. 1999; Felten et al. 2002). According to Lee et al. (2004), this test is also recommended for detection of MRSA of animal origin. Susceptibility of staphylococci to penicillin was determined by production of ß-lactamase, using the chromogenic cephalosporin method (Nitrocefin, Oxoid). Susceptibility to clindamycin, if simultaneous with resistance to erythromycin, was verified by modified disk diffusion test (D-test) where the zone around the clindamycin disk was narrowed in the section adjacent to the erythromycin disk (Rich et al. 2005).

To evaluate production of ESBL in the strains of Escherichia coli with MIC higher than $1 \mathrm{mg} / 1$ for at least one of the tested third generation cephalosporins (cefoperazone, cefotaxime, ceftazidime), the double-disk synergy test (DDST) was used, first described by Jarlier et al. (1988).

The mecA gene in Staphylococcus aureus isolate with confirmed PBP2a was detected by PCR with mecA-F (5'-TCCAGATTACAACTTCACCAGG-3') and mecA-R (5'-CCACTTCATATCTTGTAACG-3') primers (Oliveira and De Lencastre 2002). One colony of the 24-h culture of Staphylococcus aureus on meat-peptone agar was transferred to $150 \mu \mathrm{l}$ of deionized sterile water and heated to $99^{\circ} \mathrm{C}$ for $15 \mathrm{~min}$ under gentle shaking (Thermomixer comfort, Eppendorf). The suspension was centrifuged (16 $128 \mathrm{~g}, 2 \mathrm{~min}$ ) and the supernatant with partially purified DNA was used for PCR. The $49-\mu 1$ reaction mixture was prepared as follows: $42.2 \mu 1$ of $\mathrm{H}_{2} \mathrm{O}$; $5 \mu \mathrm{l} 10 \times$ reaction buffer; $0.4 \mu \mathrm{l}$ dNTPs $(10 \mathrm{mM}) ; 0.5 \mu \mathrm{l}$ of individual primers $(100 \mu \mathrm{M})$ and $0.4 \mu \mathrm{l}$ of Taq polymerase $(5 \mathrm{U} / \mu \mathrm{l})$ (dNTPs Promega; primers Eastport; other components Top-Bio). $1 \mu \mathrm{l}$ of DNA isolated from the tested bacterial isolate was added to the reaction mixture and coated with a layer of mineral oil (Top-Bio). In the negative control sample, $1 \mu \mathrm{l}$ of deionized water was added instead of isolated DNA.

The PCR was performed in a minicycler (MJ Research) in the following program: $94{ }^{\circ} \mathrm{C} 5 \mathrm{~min}, 94{ }^{\circ} \mathrm{C} 1 \mathrm{~min}$, $57{ }^{\circ} \mathrm{C} 1 \mathrm{~min}$ and $72{ }^{\circ} \mathrm{C} 1 \mathrm{~min}$. The cycle was repeated 30 times, with the final step at $72{ }^{\circ} \mathrm{C}$ for $10 \mathrm{~min}$. PCR products were analysed by gel electrophoresis in $2 \%(\mathrm{w} / \mathrm{v})$ agarose gel. The size of amplified products was estimated by comparison with a DNA ladder marker (200 - 1500 bp, Top-Bio).

\section{Results}

A total of 115 strains of Staphylococcus spp., 61 strains of Enterococcus spp., and 111 strains of Escherichia coli were isolated from the piglet rectal swabs. Of the 115 isolated staphylococci, 110 strains were found to be coagulase-negative, 5 strains were identified as Staphylococcus aureus. From the group of 110 coagulase-negative staphylococci, species identification was possible in 104 strains, whereas adequate identification by available tests was not achieved in 6 strains. The species proportion within the isolated staphylococci is shown in Table 1. The results show that the most frequent strains were Staphylococcus sciuri (26.1\%), Staphylococcus lentus (22.6\%), Staphylococcus hominis (13.9\%) and Staphylococcus simulans (10.4\%).

In the group of isolated staphylococci, 5 strains of Staphylococcus aureus were isolated.

Table 1. Overview of species of the isolated staphylococci

\begin{tabular}{|l|c|c|}
\hline Species & Number of strains & Percentage \\
\hline Staphylococcus sciuri & 30 & 26.1 \\
\hline Staphylococcus lentus & 26 & 22.6 \\
\hline Staphylococcus hominis & 16 & 13.9 \\
\hline Staphylococcus simulans & 12 & 10.4 \\
\hline Staphylococcus schleiferi & 8 & 7.0 \\
\hline Staphylococcus sp. ${ }^{*}$ & 6 & 5.2 \\
\hline Staphylococcus aureus & 5 & 4.3 \\
\hline Staphylococcus warneri & 5 & 4.3 \\
\hline Staphylococcus pulvereri & 4 & 3.5 \\
\hline Staphylococcus cohnii & 3 & 2.6 \\
\hline
\end{tabular}

* Coagulase-negative staphylococci of unidentified species
It is of crucial importance that one of them was identified as a methicillinresistant strain with simultaneous resistance to penicillin, erythromycin, clindamycin and gentamicin. For this strain, the oxacillin MIC was $8 \mathrm{mg} / \mathrm{l}$. At the same time, latex agglutination confirmed the presence of PBP2a. Resistance to oxacillin was confirmed by positive detection of the mecA gene.

Of the 110 coagulase-negative staphylococci, $47(42.7 \%)$ strains were shown to have the oxacillin MIC $\geq 0.5 \mathrm{mg} / \mathrm{l}$. The dominating species was Staphylococcus sciuri $(57.4 \%)$, as seen in Table 2 showing the relevant species proportion.

The overall resistance of the 110 isolated coagulase-negative staphylococci to antibiotics is shown in Table 3. The highest numbers of resistant isolates were found in relation to penicillin $(74.5 \%)$, tetracycline $(59.1 \%)$, erythromycin $(30.0 \%)$ and clindamycin $(30.0 \%)$. No 
Table 2. Overview of species of coagulase-negative staphylococci with the oxacillin MIC $\geq 0.5 \mathrm{mg} / 1$

\begin{tabular}{|l|c|c|}
\hline Species & Number of strains & Percentage \\
\hline Staphylococcus sciuri & 27 & 57.4 \\
\hline Staphylococcus lentus & 6 & 12.8 \\
\hline Staphylococcus hominis & 4 & 8.5 \\
\hline Staphylococcus simulans & 3 & 6.4 \\
\hline Staphylococcus schleiferi & 2 & 4.3 \\
\hline Staphylococcus warneri & 1 & 2.1 \\
\hline Staphylococcus sp. & 4 & 8.5 \\
\hline
\end{tabular}

resistant strains were recorded in the cases of vancomycin, teicoplanin and cotrimoxazole.

One strain of Staphylococcus hominis showed susceptibility to clindamycin, simultaneously with resistance to erythromycin. However, as the D-test was positive, susceptibility to clindamycin was apparently false.

Table 3. Resistance of 110 coagulase-negative Staphylococcus spp. strains to antibiotics, including the $\mathrm{MIC}$ range, $\mathrm{MIC}_{50}$ and $\mathrm{MIC}_{90}$

\begin{tabular}{|l|c|c|c|c|c|}
\hline Antibiotic & $\begin{array}{c}\text { breakpoint used } \\
(\mathrm{mg} / \mathrm{l})\end{array}$ & MIC range $(\mathrm{mg} / \mathrm{l})$ & $\begin{array}{c}\mathrm{MIC}_{50} \\
(\mathrm{mg} / \mathrm{l})\end{array}$ & $\begin{array}{c}\mathrm{MIC}_{90} \\
(\mathrm{mg} / \mathrm{l})\end{array}$ & $\begin{array}{c}\text { resistance } \\
(\%)\end{array}$ \\
\hline penicillin & - & - & - & - & 74.5 \\
\hline oxacillin & - & $0.06-1$ & 0.25 & 0.5 & $*$ \\
\hline erythromycin & 0.5 & $0.06-8$ & 0.25 & 2 & 30.0 \\
\hline clindamycin & 0.5 & $0.03-8$ & 0.25 & 2 & 30.0 \\
\hline chloramphenicol & 4 & $0.25-32$ & 1 & 8 & 7.3 \\
\hline tetracycline & 2 & $0.5-64$ & 4 & 16 & 59.1 \\
\hline vancomycin & 2 & $0.125-2$ & 0.5 & 1 & 0 \\
\hline teicoplanin & 8 & $0.25-4$ & 0.5 & 2 & 0 \\
\hline ciprofloxacin & 1 & $0.03-2$ & 0.125 & 0.25 & 0.9 \\
\hline cotrimoxazole & 32 & $0.5-8$ & 2 & 8 & 0 \\
\hline
\end{tabular}

* - resistance percentage not stated

The Enterococcus spp. isolates exhibited a high frequency of strains resistant to tetracycline $(98.5 \%)$, erythromycin $(86.8 \%)$ and chloramphenicol $(54.4 \%)$. By contrast, $100 \%$ susceptibility was documented in ampicillin, vancomycin and teicoplanin. It is obvious that the vancomycin-resistant enterococcus was not isolated (Table 4).

Table 4. Resistance of 61 Enterococcus spp. strains to antibiotics, including the MIC range, $\mathrm{MIC}_{50}$ and $\mathrm{MIC}_{90}$

\begin{tabular}{|l|c|c|c|c|c|}
\hline Antibiotic & $\begin{array}{c}\text { breakpoint used } \\
(\mathrm{mg} / \mathrm{l})\end{array}$ & MIC range (mg/l) & $\begin{array}{c}\mathrm{MIC}_{50} \\
(\mathrm{mg} / \mathrm{l})\end{array}$ & $\begin{array}{c}\mathrm{MIC}_{90} \\
(\mathrm{mg} / \mathrm{l})\end{array}$ & $\begin{array}{c}\text { resistance } \\
(\%)\end{array}$ \\
\hline ampicillin & 8 & $0.25-2$ & 0.5 & 1 & 0 \\
\hline erythromycin & 0.5 & $0.03-16$ & 4 & 8 & 86.8 \\
\hline chloramphenicol & 4 & $1-64$ & 8 & 16 & 54.4 \\
\hline tetracycline & 2 & $0.25-64$ & 16 & 32 & 98.5 \\
\hline vancomycin & 2 & $0.125-2$ & 0.5 & 1 & 0 \\
\hline teicoplanin & 8 & $0.125-0.5$ & 0.25 & 0.5 & 0 \\
\hline nitrofurantoin & 32 & $2-128$ & 8 & 16 & 4.4 \\
\hline
\end{tabular}

Resistance of the tested strains of Escherichia coli to antibiotics is presented in Table 5. The results suggest relatively high susceptibility of these strains. Higher frequencies of resistant isolates were only documented in tetracycline $(81.1 \%)$ and ampicillin $(62.2 \%)$. In total, 12 strains $(10.8 \%)$ were resistant to 3 antimicrobial agents simultaneously, i.e. these may be characterized as multiresistant. In 4 isolates, the cefoperazone MIC ranged from 2 to $4 \mathrm{mg} / \mathrm{l}$, however, the DDST result was negative in all cases. 
Table 5. Resistance of 111 Escherichia coli strains to antibiotics, including the $\mathrm{MIC}$ range, $\mathrm{MIC}_{50}$ and $\mathrm{MIC}_{90}$

\begin{tabular}{|l|c|c|c|c|c|}
\hline Antibiotic & $\begin{array}{c}\text { breakpoint used } \\
(\mathrm{mg} / \mathrm{l})\end{array}$ & MIC range (mg/l) & $\begin{array}{c}\mathrm{MIC}_{50} \\
(\mathrm{mg} / \mathrm{l})\end{array}$ & $\begin{array}{c}\mathrm{MIC}_{90} \\
(\mathrm{mg} / \mathrm{l})\end{array}$ & $\begin{array}{c}\text { resistance } \\
(\%)\end{array}$ \\
\hline ampicillin & 4 & $0.25-128$ & 8 & 64 & 62.2 \\
\hline ampicillin/sulbactam & 8 & $0.25-32$ & 1 & 4 & 1.8 \\
\hline piperacillin & 16 & $0.5-64$ & 2 & 8 & 3.6 \\
\hline piperacillin/tazobactam & 16 & $0.25-4$ & 1 & 2 & 0 \\
\hline cefazolin & 4 & $1-32$ & 1 & 4 & 7.2 \\
\hline cefuroxime & 4 & $0.25-4$ & 1 & 2 & 0.9 \\
\hline cefoxitin & 4 & $0.25-2$ & 1 & 2 & 0 \\
\hline cefoperazone & 8 & $0.06-4$ & 0.125 & 0.5 & 0 \\
\hline cefotaxime & 4 & $0.03-0.5$ & 0.06 & 0.125 & 0 \\
\hline ceftazidime & 4 & $0.03-0.5$ & 0.06 & 0.125 & 0 \\
\hline cefepime & 4 & $0.03-0.5$ & 0.06 & 0.125 & 0 \\
\hline meropenem & 4 & $0.03-0.5$ & 0.06 & 0.125 & 0 \\
\hline gentamicin & 4 & $0.06-0.5$ & 0.125 & 0.25 & 0 \\
\hline tobramycin & 4 & $0.125-4$ & 0.25 & 1 & 0 \\
\hline amikacin & 8 & $0.25-8$ & 0.5 & 2 & 0 \\
\hline ofloxacin & 2 & $0.03-0.5$ & 0.125 & 0.25 & 0 \\
\hline ciprofloxacin & 1 & $0.001-0.25$ & 0.06 & 0.125 & 0 \\
\hline colistin & 4 & $0.125-1$ & 0.25 & 0.5 & 0 \\
\hline tetracycline & 2 & $1-64$ & 16 & 32 & 81.1 \\
\hline chloramphenicol & 42 & $0.25-128$ & 2 & 4 & 5.4 \\
\hline cotrimoxazole & & $0.25-128$ & 1 & 64 & 10.8 \\
\hline
\end{tabular}

\section{Discussion}

Bacterial resistance to antibiotics presents an important and dangerous problem in relation to both therapy of potential infections and epidemiology. One of the health risks posed by infection or colonization of humans with multiresistant species is the contamination of foods or raw materials by these strains. In pigs, the main threat is contamination of slaughtered pigs by their bowel contents. These issues are dealt with by monitoring the selected zoonotic agents by the State Veterinary Administration of the Czech Republic (SVA). The monitoring includes microbiological examination of swabs obtained from processed pig carcasses focusing on Salmonella spp., Escherichia coli O157, Enterococcus faecalis and Enterococcus faecium (SVA Guideline 2005 ${ }^{\mathrm{a}, \mathrm{b}}$ ). A summary report of the results of antibiotic resistance of the monitored pathogens and indicator microorganisms has not been published as yet. The frequency of multiresistant isolates from processed pig carcasses is closely related to the level of slaughterhouse hygiene and potential previous antibiotic therapy of the slaughtered animals. Moreover, the above-mentioned monitoring does not deal with the issues of coagulase-positive staphylococci. The present pilot study focused on very young piglets for two reasons. Firstly, the examined animals had not been exposed to a direct influence of antibiotics but had been colonized after their birth with both bacterial microflora of their mothers and environmental microflora. Therefore, they represent "an indicator" of the microbial spectrum and potential of the pig population at the beginning of its reproductive period. Secondly, simultaneous single sampling of a large number (100) of swabs was easier. Moreover, the spectrum of microorganisms was extended by staphylococci in contrast to the SVA monitoring.

In our set of Staphylococcus aureus strains isolated from piglets, one MRSA was identified. This finding may be considered extremely serious and alarming. Higher 
frequency of coagulase-negative staphylococci (43\%) with the oxacillin MIC exceeding $0.25 \mathrm{mg} / \mathrm{l}$ is also suggestive of high resistance. However, the oxacillin breakpoint value for staphylococci is rather problematic. The performance standards for antimicrobial susceptibility testing (CLSI 2007) recommend $2 \mathrm{mg} / \mathrm{l}$ for Staphylococcus aureus and Staphylococcus lugdunensis strains and $0.25 \mathrm{mg} / 1$ for coagulase-negative staphylococci (except for Staphylococcus lugdunensis). This corresponds with the conclusions of Hájek et al. (2002) documenting the presence of the mecA gene in $29 \%$ of tested strains of Staphylococcus epidermidis classified as susceptible with the 2-mg/l breakpoint, which suggests false susceptibility. In their study, Tenover et al. (1999) recommended the oxacillin breakpoint value for coagulase-negative staphylococci to be $0.25 \mathrm{mg} / \mathrm{l}$, although they pointed out to potential false resistance in mecA-negative strains of some species, in particular of Staphylococcus warneri, Staphylococcus capitis, Staphylococcus lugdunensis and Staphylococcus saprophyticus. False resistance to oxacillin is also possible in the case of Staphylococcus scuiri strains accounting for $57 \%$ of isolates with the oxacillin MIC $\geq$ $0.5 \mathrm{mg} / \mathrm{l}$ in the presented study. Stepanović et al. (2006) found that Staphylococcus sciuri strains with positive demonstration of the mecA gene exhibited the oxacillin MIC of at least $2 \mathrm{mg} / \mathrm{l}$. At the same time it must be taken into account that decreased susceptibility may be also due to PBP alterations other than PBP2a and the absence of the mecA gene may not necessarily be suggestive of the effects of oxacillin or methicillin (Tenover et al. 1999). Therefore, exact resistance criteria are extremely difficult to determine.

Of particular importance is also the demonstrated existence of inducible resistance to clindamycin in the Staphylococcus hominis strain. This type of resistance is conditioned by a change in the ribosome target site encoded by the erm genes (Rich et al. 2005). Phenotypically, it is manifested by simultaneous resistance to erythromycin and clindamycin (the so called constitutive type) or by resistance to erythromycin and susceptibility to clindamycin (inducible type). In the case of the inducible type, resistance cannot be demonstrated by the common disk diffusion or microdilution methods so the aforementioned D-test must be used. If the result is positive the clindamycin result must be changed to resistant.

The favourable outcome of the presented study is no isolation of VRE previously found in poultry kept in the same region (Kolár et al. 2000, 2005). On the other hand, high resistance to tetracycline was detected, which may be related to a clonal spread of resistant strains and antibiotic medication in use. No antibiotics were administered either to the sampled piglets or to their mothers in the week prior to farrowing. However, no reliable historical data were available concerning the spectrum and amounts of antibiotics used on the farm in the past.

In the case of Escherichia coli, strains resistant to tetracycline and ampicillin were found to be more frequent. Resistance to ampicillin is probably conditioned by production of the TEM-1 and TEM-2 ß-lactamases. However, neither production of broad-spectrum $\beta$-lactamases nor resistance to fluoroquinolones were demonstrated.

The present study may be considered as a pilot project assessing the prevalence of resistant bacteria in piglets kept on a single farm. It demonstrated the presence of resistant strains of Staphylococcus spp., including once MRSA strain, Enterococcus spp. and Escherichia coli. These strains may be present as a result of postnatal colonization with both bacterial microflora of piglet mothers and environmental microflora.

\section{Rezistence k antibiotikům u kmenů Staphylococcus spp., Enterococcus spp. a Escherichia coli izolovaných z rektálních výtěrů prasat}

Cílem práce bylo stanovení úrovně rezistence vybraných bakteriálních druhů (Escherichia coli, Staphylococcus spp., Enterococcus spp.) k antimikrobním prŕípravkům v chovu prasat. Testované kmeny byly izolovány od selat ve stáŕí od 7 do 30 dnů. K identifikaci bakteriálních druhů byly použity standardní mikrobiologické postupy a citlivost $\mathrm{k}$ antibiotikům byla 
určena kvantitativně diluční mikrometodou. Rezistence k oxacilinu u kmene Staphylococcus aureus byla potvrzena průkazem mecA genu a PBP2a. Celkem bylo shromážděno 115 izolátů Staphylococcus spp. V př́padě stafylokoků byl identifikován methicilin-rezistentní kmen Staphylococcus aureus (MRSA) a současně byla zaznamenána vyšší frekvence výskytu koaguláza-negativních stafylokoků s minimální inhibiční koncentrací oxacilinu $\geq 0,5 \mathrm{mg} / \mathrm{l}$. Dále byla prokázána inducibilní rezistence ke klindamycinu u kmene Staphylococcus hominis. Kmeny Enterococcus spp. (61 izolátů) vykazovaly vysokou rezistenci k tetracyklinu $(98,5 \%)$, erytromycinu $(86,8 \%)$ a chloramfenikolu (54,4\%). Vankomycin-rezistentní enterokoky nebyly izolovány. V príípadě kmenů Escherichia coli (111 izolátů) byla dokumentována vyšší četnost rezistentních kmenů $\mathrm{k}$ tetracyklinu $(81,1 \%)$ a ampicilinu $(62,2$ \%). Rezistence $\mathrm{k}$ fluorochinolonům a produkce širokospektrých ß-laktamáz nebyla zaznamenána. Předkládaná studie může být charakterizována jako pilotní projekt pro zhodnocení prevalence rezistentních bakterií u selat na jednotlivých farmách. Studie ukázala prítomnost rezistentních kmenů Staphylococcus spp., včetně jednoho kmene MRSA, Enterococcus spp. a Escherichia coli. Tyto kmeny můžou být př́tomny v důsledku postnatální kolonizace bakteriální mikroflorou matek selat a environmentální mikroflórou.

\section{Acknowledgement}

The study was supported by the grants IGA 1A/8258-3, IGA NR9065-3 and MSM6198959223, Czech Republic.

\section{References}

BUSSCHER JF, VAN DUIJKEREN E, VAN OLDRUITENBORGH-OOSTERBAAN MMS 2006: The prevalence of methicillin-resistant staphylococci in healthy horses in the Netherlands. Vet Microbiol 113: 131-136

CAVASSINI M, WENGER A, JATON K, BLANC DS, BILLE J 1999: Evaluation of MRSA-screen, a simple anti-PBP 2a slide latex agglutination kit, for rapid detection of methicillin resistance in Staphylococcus aureus. J Clin Microbiol 37: 1591-1594

FELTEN A, GRANDRY B, LAGRANGE PH, CASIN I 2002: Evaluation of three techniques for detection of low-level methicillin-resistant Staphylococcus aureus (MRSA): a disk diffusion method with cefoxitin and moxalactam, the Vitek 2 system, and the MRSA-screen latex agglutination test. J Clin Microbiol 40: 2766-2771

GORTEL K, CAMPBELL KL, KAKOMA I, WHITTEM T, SCHAEFFER DJ, WEISIGER RM 1999: Methicillin resistance among staphylococci isolated from dogs. Am J Vet Res 60: 1526-1530

HÁJEK V, PANTUČEK R, KOLÁŘ M, DOŠKAR J, ROSYPAL S 2002: Comparison of MRSA-screen latex agglutination, conventional phenotypic methods and mecA gene detection for identification of oxacillin resistance in staphylococci. Biologia 57: 729-738

JARLIER V, NICOLAS MH, FOURNIER G, PHILIPPON A 1988: Extended broad-spectrum $\beta$-lactamases conferring transferable resistance to newer $\beta$-lactam agents in Enterobacteriaceae: hospital prevalence and susceptibility patterns. Rev Infect Dis 10: 867-878

KOLÁR̆ M, BARDOŇ J, VÁGNEROVÁ I, HÁJEK V, BZDIL J, KOHNOVÁ I, TYPOVSKÁ H 2000: Occurrence of vancomycin-resistant enterococci in hens in the central region of Moravia. Vet Med 45: 93-97

KOLÁR̆ M, PANTƯČEK R, BARDOŇ J, ČEKANOVÁ L, KESSELOVÁ M, SAUER P, VÁGNEROVÁ I, KOUKALOVÁ D 2005: Occurrence of vancomycin-resistant enterococci in humans and animals in the Czech Republic between 2002 and 2004. J Med Microbiol 54: 965-967

LEE JH 2003: Methicillin (oxacillin)-resistant Staphylococcus aureus strains isolated from major food animals and their potential transmission to humans. Appl Environ Microbiol 69: 6489-6904

LEE JH, JEONG JM, PARK YH, CHOI SS, KIM YH, CHAE JS, MOON JS, PARK H, KIM S, EO SK 2004 : Evaluation of the methicillin-resistant Staphylococcus aureus (MRSA) - screen latex agglutination test for detection of MRSA of animal origin. J Clin Microbiol 42: 2780-2782

LILENBAUM W, NUNES ELC, AZEREDO MAI 1998: Prevalence and antimicrobial susceptibility of staphylococci isolated from the skin surface of clinically normal cats. Lett Appl Microbiol 27: 224-228

State Veterinary Administration Guideline No.1/2005 ${ }^{\text {a }}$

State Veterinary Administration Guideline No. 3/2005

OLIVEIRA DC, DE LENCASTRE H 2002: Multiplex PCR strategy for rapid identification of structural types and variants of the mec element in methicillin-resistant Staphylococcus aureus. Antimicrob Agents Chemother 46: $2155-2161$

O'MAHONY R, ABBOTT Y, LEONARD FC, MARKEY BK, QUINN PJ, POLLOCK PJ, FANNING S, ROSSNEY AS 2005: Methicillin-resistant Staphylococcus aureus (MRSA) isolated from animals and veterinary personnel in Ireland. Vet Microbiol 109: 285-296 
Performance standards for antimicrobial susceptibility testing; seventeenth informational supplement. M100-S17. Clinical and Laboratory Standards Institute (CLSI), Wayne, Pennsylvania 2007, 182 p.

Methods for dilution antimicrobial susceptibility tests for bacteria that grow aerobically; approved standard. $7^{\text {th }} \mathrm{ed}$. M7-A7. Clinical and Laboratory Standards Institute (CLSI), Wayne, Pennsylvania 2006, 64 p.

RICH M, DEIGHTON L, ROBERTS L 2005: Clindamycin-resistance in methicillin-resistant Staphylococcus aureus isolated from animals. Vet Microbiol 111: 237-240

SEGUIN JC, WALKER RD, CARON JP, KLOOS WE, GEORGE CG, HOLLIS RJ, JONES RN, PFALLER MA 1999: Methicillin-resistant Staphylococcus aureus outbreak in a veterinary teaching hospital: potential humanto-animal transmission. J Clin Microbiol 37: 1459-1463

STEPANOVIĆ S, HAUSCHILD T, DAKIĆ I, AL-DOORI Z, ŠVABIĆ-VLAHOVIĆ M, RANIN L, MORRISON D 2006: Evaluation of phenotypic and molecular methods for detection of oxacillin resistance in members of the Staphylococcus sciuri group. J Clin Microbiol 44:934-937

TENOVER FC, JONES RN, SWENSON JM, ZIMMER B, McALLISTER S, JORGENSEN JH 1999: Methods for improved detection of oxacillin resistance in coagulase-negative staphylococci: Results of a multicenter study. J Clin Microbiol 37: 4051-4058

VAN DUIJKEREN E, BOX ATA, HECK MEOC, WANNET WJB, FLUIT AC 2004: Methicillin-resistant staphylococci isolated from animals. Vet Microbiol 103: 91-97

VENGUST M, ANDERSON MEC, ROUSSEAU J, WEESE JS 2006: Methicillin-resistant staphylococcal colonization in clinically normal dogs and horses in the community. Lett Appl Microbiol 43: 602-606

WALLER A 2005: The creation of a new monster: MRSA and MRSI - important emerging veterinary and zoonotic diseases. Vet J 169: 315-316

WEESE JS, ARCHAMBAULT M, WILLEY BM, DICK H, HEARN R, KREISWIRTH BN, SAID-SALIM B, MC GEER A, LIKHOSHVAY Y, PRESCOTT JF, LOW DE 2005: Methicillin-resistant Staphylococcus aureus in horses and horse personnel, 2000 - 2002. Emerg Infect Dis 11: 430-435 